\title{
pÿAKP s income-differentiated housing strategies under the pressure of resistance and debt
}

\section{Celik, Özlem}

\section{Zed Books}

2020-08-26

pÿCelik, Ö 2020 , AKP s income-differentiated housing strategies under the pressure of pÿresistance and debt . in P Bedirhanoglu , C Dolek, F Hulagu \& O Kaygusuz (eds), Turkey s New State in the Making : Transformations in Legality, Economy, Ideology and Coercion . Zed Books, London, pp. 151-164.

http://hdl.handle.net/10138/326308

acceptedVersion

Downloaded from Helda, University of Helsinki institutional repository.

This is an electronic reprint of the original article.

This reprint may differ from the original in pagination and typographic detail.

Please cite the original version. 


\title{
AKP's income-differentiated housing strategies under the pressure of resistance and debt
}

\author{
Özlem Çelik
}

(forthcoming) Turkey's New State in the Making: Transformations in Legality, Economy, Ideology and Coercion, Bedirhanoglu, P., C. Dolek, F. Hulagu and O. Kaygusuz (Eds.), London: ZED.

\section{Introduction}

This chapter examines the income-differentiated housing provision strategies of the state under the AKP rule after the 2001 economic crisis, which prepared the ground for historical changes in the housing policy in Turkey. In the existing literature, the growth of housing sector in the economy is portrayed as one of the main targets of the AKP's economic program based on the bourgeoning construction sector. While this is definitely an important issue to understand the current conditions of capital accumulation in the country, this chapter will attract attention to the central political role attributed by the AKP to the housing sector in the creation of consent to its rule. Due to this focus, the chapter will prioritize the developments on the demand side of the housing provision process more, while making relatively limited analysis on the suppliers except the big public players in the sector. Based on the findings of two field researches conducted in İstanbul in 2016 and 2017-2018, ${ }^{1}$ it will argue that the state has played a deliberate mediator role in creating a new and lucrative housing market on the public lands and gecekond $u^{2}$ areas within the context of the financializing Turkish economy since 2002. ${ }^{3}$ Furthermore, due to the economic and political opportunities, as well as risks this process comprises, it has followed carefully designed housing strategies, differentiated on the basis of income and redefined persistently under changing market conditions and resistances. The mediator role of the state has thus been shaped by the initial conditions of the AKP government's economic program, as well as the contingent interaction between global financial flows into the built environment and the social and economic tensions and risks accumulating in the housing field.

The period after the 2001 crisis witnessed significant changes in the housing policy in Turkey. This meant a series of new legislations in urban governance and housing provision in the early years of the AKP rule, leading to cycles of centralisation and decentralisation in urban planning powers. Changing power relations between different scales were shaped by the EU membership process, the new economic measures imposed by the IMF-World Bank program

\footnotetext{
${ }^{1}$ This chapter is based partially on research undertaken as part of the project titled "Financialization, Economy, Society, and Sustainable Development (FESSUD 2011-2016)," which received funding from the EU Seventh Framework Program (FP-7/2007-2013) under grant agreement no. 266800, and a revisit research to understand the latest strategies of the state in housing in 2018, funded by the Swedish Institute under grant agreement no. $23997 / 2017$. While the first half of the research was made in 2016 , a second phase of the research was conducted in 2018 to grasp the current stage of changing strategies of the state.

${ }^{2}$ Self-help housing is called gecekondu in Turkish, which literally means "built-overnight."

${ }^{3}$ See Çelik forthcoming.
} 
of 2001, ${ }^{4}$ and the 2003 McKinsey Report targeting growth in the construction sector as a remedy for the crisis. ${ }^{5}$ The new economic program of the AKP included measures that aimed to attract global capital to invest in the built environment in Turkey. This was a strategy that was designed to fulfil the interests of investors on the one side, and to provide the government with a political room of manoeuvre in the housing sector. One of the main effects of this new economic program was the change in the housing policy, which envisaged the provision of housing to different groups in the society via the promotion of homeownership, and the redefinition of the housing market by the ownership-based model. The state has played the leading role in the expansion, regulation and promotion of this new housing agenda for both attracting investors into the housing market and involving consumers in the homeownership model. ${ }^{6}$

The newly developing housing sector has been defined by differing demands and conflicting interests. The large-scale developers and upper- and middle-income households have been in favor of the state's new housing strategies including the lowering of the interest rates of the loans and the promotion of new financial tools. The poor, however, have resisted powerfully against being indebted due to the forced regeneration process in their neighborhoods in the big cities. The small- and medium-scale contractors have also put pressure on the state to be the active actors of the expanding house-building sector rather than serving only as subcontractors to large-scale companies. The state responded to the demands of the contractors by enacting regulations for the small-scale renewal of middle-income housing units without any displacement. The state's involvement in the making of this new housing market that would bring together the middle-income households, and small- and mediumscale contractors has been a strategy to expand the construction sector's scope in the economy. The state has played a more critical role in the housing processes affecting the lower- and upper-income groups as the field has been defined by the powerful resistance of the poor gecekondu-holders and high profit expectation of the large-scale developers and the well-off. Varieties of state strategies in housing thus reflects the class character of housing policy during particularly the last decade in Turkey. The involvement of lower-income households in homeownership carries a specific importance to understand how the constituency of the AKP has also resisted against the regeneration projects and how the Party has responded to this resistance in order not to lose their consent to its rule.

The analysis of the income-based housing strategies of the state can be made on the basis of a very limited statistical data available on mortgage and loan use in Turkey. To overcome this limitation, 24 semi-structured interviews were conducted with a variety of actors in the housing sector, including the state personnel at the local and central levels, financiers, property developers, representatives of real estate development trusts (REITs), members of the professional chambers, dwellers in neighborhoods, and activists, who have taken part in the resistance against the state-led gentrification processes. Additional to these primary sources, secondary sources including interviewees, reports, city plans, and available statistics of housing production, and mortgage and loan use were utilized. The field research comprised three important neighborhoods in Istanbul, namely Sarıyer, Maltepe and Güngören, that have been targeted by the state for new and lucrative property development. Both the importance

\footnotetext{
${ }^{4}$ Kuyucu 2017.

${ }^{5}$ Karaçimen and Çelik 2017.

${ }^{6}$ Çelik forthcoming.
} 
and the variegated character of the neighborhoods selected have provided data available for generalizations.

This paper examines firstly the historical background of housing in Turkey. As will be discussed, increased levels of global capital flows have led to a significant change in the housing policies of the AKP governments since 2002. Secondly, the income-differentiated housing strategies of the state will be analyzed to understand how the state has economically and politically recomposed particularly the poor, who have been indeed the AKP's main constituency so far despite the inequality-generating implications of neoliberalism.

\section{Tracing the changes in the housing agenda in Turkey}

Historically, there used to be varieties of housing provision methods for the lower-income households such as cooperatives, lodgments, and gecekondu housing in Turkey alongside the private housing market for the middle- and upper-income households. The new housing agenda has aimed to redefine the conditions of housing by introducing new financial tools to the market, providing long-term housing loans for middle- and upper-income households, enabling non-Turkish citizens to own land and real estate, ${ }^{7}$ and putting an end to the production of gecekondu housing by enforcing low-income households to buy new housing units from regeneration projects.

The national strategy to start a new housing program across the country was initiated by the 2003 Emergency Action Plan of the AKP, targeting: (i) the prevention of new gecekondu production and the regeneration ${ }^{8}$ of the existing ones, and (ii) indebtedness-based housing provision via financial tools. As part of the action plan, the Mass Housing Administration (Toplu Konut Idaresi Başkanlığı, hereafter TOKi), which used to be a finance institution for housing, was empowered as the central institution under the Prime Ministry, to plan and implement housing provision policies for low-, middle- and upper-income households by also giving bids to the private sector. Consequently, TOKI gained the authority for planning housing at all scales, opening bids for new housing projects, running urban regeneration (UR) projects at gecekondu neighborhoods as well as at 'risky zones' defined under the Disaster Law no. 6306, producing big-scale projects including shopping malls, schools and hospitals, and implementing revenue-sharing model for profit and non-profit housing production with private developers. While the public land stocks under the authority of a variety of state institutions were transferred to the control of TOKi, the Administration was also exempted from the Procurement Law ${ }^{9}$ for its construction practices in 2011. TOKi was also made free from budgetary controls and auditing by the High Court of Accounts in $2005 .{ }^{10}$ Following the

\footnotetext{
${ }^{7}$ By the amendment of the Real Estate Reciprocity Law in 2012, the citizens of Saudi Arabia, Qatar, Kuwait, England, and Germany were allowed to buy real estate in Turkey. See, Karaçimen and Çelik 2017. The non-Turkish citizen's homeownership almost doubled from 2013 to 2015, and after a decrease in 2016, it almost doubled again in 2018 (in the first 10 months) by 30,500 sold units. See, TÜiK 2018.

8 In the new legislation, the process of transforming the neighborhoods by demolishing, rebuilding, and displacement of the existing dwellers is called 'urban regeneration'. However, it carries a different meaning than the literature on urban regeneration. While some scholars call it 'urban transformation', some others call it 'state-led gentrification'. Both of the conceptualizations have important aspects to grasp the implementation of 'regeneration projects' that I also share. So, the concept 'regeneration' used in this chapter is loaded with critical aspects in the literature.

${ }^{9}$ The law had been changed 35 times by 2013 to include exceptional measures. See Kuyucu 2017, 63.

${ }^{10}$ Atiyas 2012.
} 
empowerment of TOKi, the state-owned Emlak Konut REIT ${ }^{11}$ was established to regulate the housing market for the upper-income housing production, to initiate large-scale projects and to facilitate the bureaucracy for investors in luxury housing market ${ }^{12}$.

In order to boost the economy via construction sector and to sustain a conflict-free planning process by the empowerment of TOKI and the establishment of Emlak Konut REIT, the state pursued to respond to the interests of global investors and domestic firms by providing them with large-scale land in city centers with new development rights and high revenues. The provision of large-scale lands was enabled by the privatization of public lands, ${ }^{13}$ including ports, forests and green areas, ${ }^{14}$ and also via UR projects in gecekondu neighborhoods. Those projects targeted the whole area of the neighborhood to turn into vacant land via the displacement of existing dwellers to the peripheries of the cities. ${ }^{15}$

\section{Housing strategies of the state for the middle- and upper-income households}

The middle- and upper-income households used to be the main components of Turkey's formal housing sector as actual or potential owners up to the 2000s. The AKP's main housing strategies towards these groups have thus aimed to increase their demand by creating the conditions for a booming and profitable sector.

The first strategy of the state to increase demand and supply in the existing housing sector and sustain capital accumulation was to expand the volume of buyers via the Mortgage Law no. 5582 enacted in 2007, the promotion of UR mortgages, and the amendment of the Real Estate Reciprocity Law in 2012. By the new mortgage law, middle-income households started to get involved in the housing market with a pace of 34 percent of the residential sales by $2016 .{ }^{16}$ The dominance of middle-income groups in mortgage lending was also because of the regulations that limited lower-income groups' involvement in the mortgage market in order to prevent the risks of a financial crisis. ${ }^{17}$ As Aslan shows in his research on İstanbul between 2010 and 2014, the users of mortgage loans hold an income, which is approximately six times the minimum wage in Turkey. ${ }^{18}$ The same research also showed a high education level among the mortgage holders, where the education level was quite low among the lower-income households. Thus, accessing mortgage system ${ }^{19}$ has had a class character in Turkey.

The involvement of middle-income households in the housing market was also supported by Urban Regeneration Mortgage under the Risky Zones Law, which offered mortgage to a variety of consumers, involving residents of risky buildings, tenants who lived in a risky

\footnotetext{
11 The development of REITs and their effect on the expansion of housing and real estate sector got a pace after the establishment of Emlak Konut, which has the highest market value among the other REITs, which is almost 1 billion euros by the first quarter of 2018. See SPK 2018.

12 Interviews 1, 2, 6 and 7.

13 Demiralp et. al. 2016.

${ }^{14}$ Çarıkçı 2017.

15 Kuyucu and Ünsal 2010; Karaman 2014; Lovering and Türkmen 2011; Türkün 2011.

${ }^{16}$ Aslan and Dinçer 2018, 148.

${ }^{17}$ Interview 9.

${ }^{18}$ Aslan 2019, 150.

${ }^{19}$ It is important to mention that 2018-2019 economic crisis in Turkey carries a significant impact on the housing sector, where there is an important rise in housing loans of consumers and investors. To reduce the risk of having a twin crisis in the housing sector, the state started some new measures to ease the mortgage payment of consumers, loan payment of investors via campaigns. See, Çelik 2018.
} 
building at least one year, and residents living in a risky building and thereby having the demand to buy another flat. ${ }^{20}$ The UR mortgage has been made available with no payment for resource utilization support fund and no banking and insurance transaction tax. The second target of the UR policy was the middle-income housing units, mainly apartment blocks on one parcel rather than the whole neighborhood, ${ }^{21}$ that required renewal without any displacement. As mentioned before, this was a response to the demands of small- and middlescale companies and contractors in housing production ${ }^{22}$ as a part of a construction economy. This strategy aimed not only to include small- and middle-scale housing companies in housing production, but also to include a wider segment of society into financialized housing market by providing them with the UR mortgage on specific terms. The regeneration projects under this new law were also subsidized by the state through rent-support to the house-owners for eighteen months of regeneration and reduced tax for the companies. In this way, middleincome households, and small- and middle-scale housing companies started to be a part of the redistribution of capital in the growing housing sector.

While the middle- and upper income households cooperated with the state in the UR policy due to their gains of getting a new flat in return and rising rent gap, as will be discussed in the next section, the low-income households responded this new housing policy by organized resistance as the policy would lead to their ultimate dismissal from their gecekondu neighborhoods.

\section{Housing strategies for low-income households}

The housing of the poor had not been systematically regulated in Turkey up until the 2000s. During the massive migration of rural populations to the big cities in the 1950s, the state had remained largely silent to their housing needs, and self-help housing mostly on state-owned lands was promoted as a solution by the newcomers in return. The inclusion of self-help housing to the capitalist housing market via giving them legal or semi-legal status became a question of negotiation between the newcomers and the politicians at the time of elections, leading to 16 amnesty legislations and laws as a part of the improvement and development plans until the early 1990s. ${ }^{23}$ Those plans aimed to provide titles or title deeds to the habitants of the houses in exchange for certain payments. However, having a title deed for the land still left the houses out of legal recognition. This process also involved tensions and conflicts between the dwellers and state authorities. In the 1970s, in some of the neighborhoods the attempts of local authorities to knock down those housing units turned into a clash between the dwellers and the police force. ${ }^{24}$ In the 1980 s, under a populist and clientelist system, the state took some limited measures to include gecekondu units in the housing market by giving subsidies for the construction of mass housing elsewhere or in the neighborhood for gecekondu dwellers through the Mass Housing Fund. However, the housing production

\footnotetext{
${ }^{20}$ See https://www.vakifbank.com.tr/kentsel-donusum-kredisi.aspx?pagelD=871, reached on 14.05.2019.

21 Interview 7.

22 Interviews 4 and 5.

23 Özer et.al. 2007.

${ }^{24}$ Aslan 2004.
} 
stagnated under the effects of the 1990 s economic crisis, ${ }^{25}$ while the subsidies helped encourage middle-income housing production rather than housing the poor. ${ }^{26}$

The UR projects, targeting the transformation of gecekondu neighborhoods as a whole, meant a new era for gecekondu housing. Following the 2003 Emergency Action Plan of the AKP, the new UR policies have displaced urban planning procedures via bypassing different levels of decision-making processes. Since 2005, when the first UR law enacted, the UR schemes have varied for gecekondu neighborhoods, dilapidated housing areas in the historical parts of the cities, and different income-household neighborhoods in the country. In the initial phase of the UR projects, the first target was the demolishment of whole gecekondu neighborhoods and the displacement of existing dwellers to the peripheries of the cities, where mass housing units are constructed by TOKI, though only for the 'rightful owners' excluding the tenants. The main consequences of this zero-tolerance scheme were displacement due to forced-eviction, and homelessness due to the dispossession of the dwellers with no or insufficient income to afford the units, ${ }^{27}$ as well as indebtedness. Rather than offering deeds or title deeds to the dwellers, the new scheme aimed to transfer the centrally located valuable gecekondu and dilapidated historical neighborhood lands to TOKi to use them for luxury housing under market conditions.

This housing strategy stimulated opposition in the designated neighborhoods, getting the attention and solidarity of professional chambers of urban planners and architects, civil society organizations, political groups, and parties against the UR projects. The demands of the dwellers were a decentralized decision-making process with the right to participate, not being indebted, and not to be displaced, but having in-situ regeneration, where dwellers would stay where they used to live. The resistance of the gecekondu dwellers expanded across cities, and particularly in İstanbul, where the majority of the gecekondu neighborhoods were located. The dwellers created district- and city-wide platforms and associations that act together; ${ }^{28}$ and also mobilized activists, professional chambers and political groups. ${ }^{29}$ The neighborhood resistances took different forms in every locality, including marches, neighborhood meetings, solidarity campaigns against police violence in the neighborhoods, legal cases to cancel the projects, and blocking off the construction companies to enter the neighborhoods.

In the targeted areas, 11,543 units were rapidly demolished between 2004 and 2008, which is a very high number historically. ${ }^{30}$ The new Municipality Law enabled the demolishment and rebuilding of the houses for the rightful owners through a partnership with TOKi. Following the new regulations between 2002 and 2008, the TOKI took the mere responsibility of the UR projects to construct housing for profit on state-owned lands or by urgent expropriation of land in the UR areas. ${ }^{31}$ The housing strategies of the state had to be revisited after the 2008 crisis, after particularly a number of poll defeats at the district level in the 2009 local elections. ${ }^{32}$ The political defeats of the AKP were mostly in districts, where there were coercive

\footnotetext{
25 Öktem Ünsal 2015.

${ }^{26}$ Gülöksüz 2009.

${ }^{27}$ Lovering and Türkmen 2011.

28 Interviews 13, 14, 15, 16, and 17.

${ }^{29}$ Interviews 10, 11, 12, 13, 14, 15, 16, and 17.

${ }^{30}$ Kuyucu and Ünsal 2010, 1484.

31 Ibid.

${ }^{32}$ Sakarya 2011; Kuyucu 2014; 2017.
} 
pressures on the dwellers for regeneration purposes. The AKP's response to this has been the promotion of some cooperative measures to get the consent of the dwellers in those neighborhoods as well as some new redistributive mechanisms to include small- and middlescale contractors in the housing market back again. The state started offering protocols at the local level in cooperation with TOKI and the greater and district municipalities to dissolve resistances or overcome obstacles in order to start UR project anew, or to continue those announced since 2004.

Making protocols at the local level depending on the contingency of the particular neighborhood has been defined as a strategy during the negotiation process between the dwellers and the district municipality representatives. ${ }^{33}$ While this method started in gecekondu neighborhoods, the main aim of making protocols has been to get the consent of all dwellers to launch the projects. The process of getting consent has included negotiations on the right to housing, including in-situ regeneration. By the help of this method, the dwellers started to agree with the loaning terms of the municipality and the TOKI, while the state has ensured available negotiation channels to continue regeneration in central gecekondu neighborhoods in the big cities. ${ }^{34}$ However, as the dwellers said in the interviews -both those who gave their consent peacefully ${ }^{35}$ and those not, ${ }^{36}$ it is clear that they considered the process as an unavoidable one.

The second 100 Day Action Plan of the President, announced on 13 December 2018 in response to the ongoing economic crisis, also supported the method of local protocols by an emphasis on empowering the social dimension of the UR projects at the stages of decisionmaking and implementation. This meant the issuing of local protocols, tailored for each locality to continue with housing production plans and ensure legitimation to the whole process. The first strategy to this end has been to depoliticize organized resistance by responding some demands of the dwellers. The main tool used to depoliticize the resistance has been TOKI's acceptance of making in-situ UR projects rather than eviction-based ones. In addition to in-situ UR strategy, making agreements with the dwellers individually has been another one, creating conflicts among dwellers in relation to the agreed value of their assets in the neighborhood. Individual negotiations have brought varying payments or subsidies to dwellers. This strategy was a part of divide and rule understanding to depoliticize the dwellers. $^{37}$

The second strategy has been to create vacant land for investors to provide economic prosperity in the time of recession in the housing sector in Turkey. After the shift of UR projects from eviction-based to in-situ-based, the existing dwellers of the neighborhoods have been directed to move to high-density apartment blocks in the same district to create vacant land for luxury housing projects. The existing parks and green areas in the neighborhoods have also been transformed into 'vacant land' by the devastation of nature. ${ }^{38}$

\footnotetext{
33 Interviews 19 and 20.

34 Interview 18.

35 Interviews 23 and 24.

${ }^{36}$ Interviews 21 and 22.

${ }^{37}$ Interviews 21, 22, 23, and 24.

38 Interviews 11, 14, 15, and 18.
} 
Another strategy to expand homeownership among the poor is to promote campaigns ${ }^{39}$ offering a variety of payment models for the consumers, including reductions when the whole payment of the house loan is made. TOKi produced 500,000 new housing units from 2007 to 2011 in total, ${ }^{40}$ while the housing produced for the poor remained very limited. ${ }^{41}$ The recent data on the affordability of housing in Turkey show that the rising number of housing production by the state does not mean enough number of affordable housing for low-income households. ${ }^{42}$ While the private sector remains out of the housing production for low-income households, the number of housing units produced by TOKi is still very low. Lower-income groups' limited affordability has been due to the high regular expenses in new housing units such as management fees, as well as expensive housing loans, higher rents, long- or shortterm unemployment, and the low number of people working in each household. ${ }^{43}$ The new strategies to involve low-income households in homeownership have hence remained inadequate so far.

\section{Conclusion}

This chapter has made a discussion on the changing role of the state in housing production by analyzing the housing policy changes and strategies since 2001. It has argued that the state plays a significant role for the inclusion of different segments of income groups in homeownership by designing the construction sector and financial institutions to this end. However, the strategies and tactics of the state have varied from repressive to more cooperative ones due to the growth expectations built on the construction sector and political expectations of the AKP to stay in power by meeting the demands of different classes. This process has been a rather conflictual one.

The conflicts between the dwellers and the state have been more evident since 2005, after the economic crisis and strong resistance in UR neighborhoods, where the whole dwellers were forced to move to the peripheries of the cities as a part of the state's revenue-sharing model of housing production. This top-down UR policy led to coercive measures to relocate poor habitants of gecekondu settlements out of the centers of the cities, hence faced organized resistance of the dwellers against the UR. The resistance of the dwellers has created problems for the accumulation of capital in the housing sector. To overcome this obstacle the state has started to implement new cooperative measures to continue urban regeneration, the most important of which has been opening up negotiation process between the dwellers and state institutions. However, as the dwellers and state institutions do not have the same power in the negotiation process, while negotiations have created uneven consequences for the dwellers depending on their specific characteristics such as their land ownership, political affiliations to the AKP, having a legal document of housing rights, and their capacity to be indebted to have a flat equivalent of what they used to have. This strategy has substantially

\footnotetext{
${ }^{39}$ The following illustrates a striking example: "Time for Turkey to Prosper" (Türkiye için kazanç vakti). See http://www.turkiyeicinkazancvakti.com/.

40 Özdemir Sarı and Aksoy Khurami 2016.

${ }^{41}$ New housing units produced for the low-income households was 11,408 units by 2009 . See, Özdemir Sarı and Aksoy Khurami 2018.

42 Özdemir Sarı and Aksoy Khurami 2018.

${ }^{43}$ Ibid.
} 
weakened the struggles in those neighborhoods, besides the dissolving effects of being indebted.

\section{References}

Aslan, A. S. (2019) "Barınma Problemine Çözüm Olarak Sunulan İpotekli Konut Kredilerine Erişilebilirliğin Değerlendirilmesi," Megaron, 14: 177-191.

Aslan, A. S. and Dinçer, I. (2018) "The Impact of Mortgage Loans on the Financialization Process in Turkey," Planlama Dergisi, 28(2): 143-53.

Aslan, Ş. (2004) 1 Mayıs Mahallesi, Istanbul: Iletisim Yayinlari.

Atiyas, i. (2012) "Economic institutions and institutional change in Turkey during the neoliberal era," New Perspectives on Turkey, 47: 57-81.

Çarıkçı, Ç. (2017) “2001 krizi sonrası Türkiye'de Büyük Ölçekli Kentsel Yatırım Projeleri: İstanbul Örneği”, in P. Bedirhanoğlu, H. Mihci and O. Çelik (eds.) Finansallaşma Kıskacında Türkiye'de Devlet, Sermaye Birikimi ve Emek, İstanbul: Notabene, 103-128.

Çelik, Ö. (forthcoming) "The Role of State in Mediating Demand and Supply in the Financialisation of Housing in Turkey".

Çelik, Ö. (2018) "Yeni Konut Kampanyaları ile Tanışın: Fedakâr Borçluluk", Ayrinti Dergisi, 28, http://ayrintidergi.com.tr/yeni-konut-kampanyalari-ile-tanisin-fedakar-borcluluk/

Demiralp, S, Demiralp, S. and Gümüş, I. (2016) "The state of property development in Turkey: facts and comparisons," New Perspectives on Turkey, 55: 85-106.

Gülöksüz, E. (2009) “inşaat Sanayinde Uluslararasılaşma ve Sermayeler Arası Iliş̧kiler," Praksis, 19: 157-189.

Karaçimen, E. and Çelik, Ö. (2017) “Türkiye'de Gayrimenkul ve Finansın Derinleşen ve Yeniden Yapılanan İlişkisi," in P. Bedirhanoğlu, H. Mıhçı and Ö. Çelik (eds.) Finansallaşma Kıskacında Türkiye'de Devlet, Sermaye Birikimi ve Emek, İstanbul: Notabene, 83-102.

Karaman, O. (2014) “Resisting urban renewal in Istanbul," Urban Geography, 35(2): 290-310.

Kuyucu, T. and Ünsal, Ö. (2010) “Urban Transformation' as State-led Property Transfer: An Analysis of Two Cases of Urban Renewal in Istanbul," Urban Studies, 47(7): 1479-1499.

Kuyucu, T. (2014) "Law, Property and Ambiguity: The Uses and abuses of Legal Ambiguity in Remaking Istanbul's Informal Settlements," International Journal of Urban and Regional Research, 38(2): 609-27.

Kuyucu, T. (2017) "Two Crisis, Two Trajectories: The Impact of the 2001 and 2008 Economic Crises on Urban Governance in Turkey," in F. Adaman, B. Akbulut and M. Arsel (eds.) Neoliberal Turkey and Its Discontents, London: IB Taurus, 44-74.

Lovering, J. and Türkmen, H. (2011) "Bulldozer neo-liberalism in Istanbul: The state-led construction of property markets, and the displacement of the urban poor," International Planning Studies, 16(1): 73-96.

Öktem-Ünsal, B. (2015) "State-led Urban Regeneration in Istanbul: Power Struggles Between Interest Groups and Poor Communities," Housing Studies, 30(8): 1299-1316. 
Özdemir Sarı, O. B. and Aksoy Khurami, E. (2018) "Housing affordability trends and challenges in the Turkish case," Journal of Housing and the Built Environment, DOI: 10.1007/s10901-0189617-2.

Özdemir Sarı, Ö.B. and Aksoy, E. (2016) "Excess Production, Rising Prices and Declining Affordability: Turkish Housing Experience", in I. Wroot (ed.) AMPS Conference Publication Series 8. Government and Housing in a Time of Crisis: Policy, Planning, Design and Delivery. Liverpool John Moores University, Liverpool, 08-09 September 2016, 162-170.

Özer, G., Vardar, A. and Nazım, M. (2007) "Unplanned Settlements within the context of Urbanization Process of Turkey," FIG Commission 3 Workshop, Athens: Greece, March 2831.

Öztürk, Ö. (2011) Türkiye'de Büyük Sermaye Grupları, 2nd ed., İstanbul: SAV.

Sakarya, i. (2011) "The Role of the Local Municipalities in the Urban Regeneration Projects of Istanbul," New Housing Researcher's Colloquium, Conference Proceeding.

SPK (2018) Sermaye Piyasası Kurulu Aylık Raporları, https://www.spk.gov.tr/SiteApps/Yayin/AyliklstatistikBultenleri , reached on 30.11.2018

Topal, A., G. L. Yalman and Ö. Çelik (2018) “Changing Modalities of Urban Redevelopment and Housing Finance in Turkey: three mass housing projects in Ankara," Journal of Urban Affairs, advance online publication, DOI: 10.1080/07352166.2018.1533378.

Türkün, A. (2011) "Urban Regeneration and Hegemonic Power Relationships," International Planning Studies, 16(1): 61-72.

\section{Interviews conducted in 2016:}

Interview 1: TOKi Ankara high ranked civil servant 1

Interview 2: TOKi Ankara high ranked civil servant 2

Interview 3: Head of the one of the REITS

Interview 4: Middle-scale housing company owner based in istanbul

Interview 5: The Turkish Employers Association of Construction Industries (INTES)

Interview 6: Emlak Konut REIT high ranked civil servant

Interview 7: Real Estate Developer based in Ankara

Interview 8: One of the previous heads of the REIT Association in Turkey

Interview 9: Manager of a well-known Commercial Bank

Interview 10: Chamber of Urban Planners

Interview 11: Chamber of Architects 1st interviewee

Interview 12: Chamber of Architects 2nd interviewee

Interview 13: Dayanismaci Atolye

Interview 14: Imece

Interview 15: Toplum İcin Sehircilik Hareketi 
Interview 16: Müştereklerimiz

Interview 17: Kuzey Ormanlari Savunmasi

Interviews conducted in 2018:

Interview 18: TOKi Istanbul Manager

Interview 19: District Municipality Representative 1

Interview 20: District Municipality Representative 2

Interview 21: Neighborhood Dweller 1 (living in gecekondu regeneration area)

Interview 22: Neighborhood Dweller 2 (living in gecekondu regeneration area)

Interview 23: Neighborhood Dweller 3 (living in gecekondu regeneration area)

Interview 24: Neighborhood Dweller 4 (living in gecekondu regeneration area) 